\title{
"Capital structure of small, medium and micro enterprises: major factors for a developing economy"
}

\begin{tabular}{|c|c|}
\hline AUTHORS & $\begin{array}{l}\text { Sharon Zunckel (D https://orcid.org/0000-0002-7150-958X } \\
\text { Celani John Nyide (D https://orcid.org/0000-0003-2883-0092 }\end{array}$ \\
\hline ARTICLE INFO & $\begin{array}{l}\text { Sharon Zunckel and Celani John Nyide (2019). Capital structure of small, } \\
\text { medium and micro enterprises: major factors for a developing economy. } \\
\text { Problems and Perspectives in Management, 17(2), 124-133. } \\
\text { doi:10.21511/ppm.17(2).2019.09 }\end{array}$ \\
\hline DOI & http://dx.doi.org/10.21511/ppm.17(2).2019.09 \\
\hline RELEASED ON & Monday, 06 May 2019 \\
\hline RECEIVED ON & Friday, 08 February 2019 \\
\hline ACCEPTED ON & Tuesday, 05 March 2019 \\
\hline LICENSE & $\begin{array}{l}(c) \text { EY } \\
\text { This work is licensed under a Creative Commons Attribution } 4.0 \text { International } \\
\text { License }\end{array}$ \\
\hline JOURNAL & "Problems and Perspectives in Management" \\
\hline ISSN PRINT & $1727-7051$ \\
\hline ISSN ONLINE & $1810-5467$ \\
\hline PUBLISHER & LLC "Consulting Publishing Company "Business Perspectives" \\
\hline FOUNDER & LLC "Consulting Publishing Company "Business Perspectives" \\
\hline
\end{tabular}

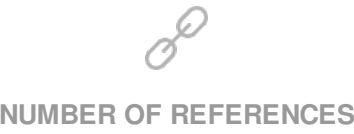

40

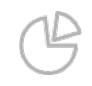

NUMBER OF FIGURES

2

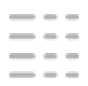

NUMBER OF TABLES

2

(C) The author(s) 2023. This publication is an open access article. 


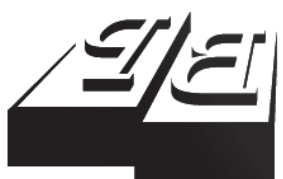

BUSINESS PERSPECTIVES

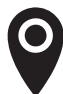

LLC "CPC "Business Perspectives" Hryhorii Skovoroda lane, 10, Sumy, 40022, Ukraine

www.businessperspectives.org

Received on: $8^{\text {th }}$ of February, 2019 Accepted on: $5^{\text {th }}$ of March, 2019

(C) Sharon Zunckel, Celani John Nyide, 2019

Sharon Zunckel, Lecturer, Department of Management Accounting, Durban University of Technology, South Africa.

Celani John Nyide, Senior Lecturer, Department of Finance and Information Management, Durban University of Technology, South Africa.

\section{(ㄷ)(i)}

This is an Open Access article, distributed under the terms of the Creative Commons Attribution 4.0 International license, which permits unrestricted re-use, distribution, and reproduction in any medium, provided the original work is properly cited.

\title{
CAPITAL STRUCTURE OF SMALL, MEDIUM AND MICRO ENTERPRISES: MAJOR FACTORS FOR A DEVELOPING ECONOMY
}

\begin{abstract}
Managing capital structure is an imperative decision made by all firms. The manner in which financing is organized is a strategic financial decision and managers must settle on the amount of debt in relation to equity that it requires to maintain. Despite many empirical studies investigating the choice of capital structure for large corporates, minimal research has been conducted on capital structure decisions in small, medium, and micro enterprises (SMMEs). This study identifies major factors influencing the capital structure of SMMEs in a developing economy and enlightens owners/managers on the importance thereof. This investigation used a quantitative research approach, which was cross-sectional. A convenience sampling method was adopted, and data were collected from 136 respondents, only confined to the retail and whole sector, which is the second largest sector in KwaZulu-Natal, South Africa. The partial least squares structural equation modelling was utilized to determine the statistical results. It was discovered that managerial factors such as individual goals and financing preference of the owner/manager, network ties, attitude to debt, maintaining control and asymmetric information; and firm-level factors such as size of the firm, profitability and firm age are major factors that influence the capital structure of SMMEs. Therefore, capital structure decisions are made motivated by the attitudes of the owners/managers.
\end{abstract}

\section{Keywords}

\section{JEL Classification G32, L21, L25}

\section{INTRODUCTION}

According to the International Leadership Development Programme (2014), there appears to be inadequate support for new start-up firms in the current retail and wholesale sectors, especially in developing economies, particularly in terms of long-term growth and sustainability. Abeywardhana (2015) citing Fatoki (2012) reveals that the SMME sector in South Africa, a developing economy, is characterized by high failure rates and about $75 \%$ of new SMMEs do not become established businesses, which has been identified as one of the highest failure percentages worldwide. Agwa-Ejon and Mbohwa (2015) establish that the main challenges facing SMMEs in developing economies relate to financing these entities. One of the foremost sources of financing available to small firms is that of personal savings and informal loans from friends and lenders (Taiwo, Falohun, \& Agwu, 2016). Other sources include partners, informal financial markets and banks, which would make up the capital structure of a small business. Once the firm is established, retained earnings become imperative to these firms, particularly SMMEs (Taiwo et al., 2016). Fourati and Affes (2013) state that the availability of external funds is limited at the start-up stage for newly created firms. Due to start-up firms not having collateral and being charged high interest rates with no flexibility in the payment 
period, private banks are often perceived as inadequate financing source for start-up firms (Silva, 2015). Due to this problem and given this difficulty, owners/managers rely heavily on internal funds.

Managing capital structure is an imperative decision made by all firms. The manner in which financing is organized is a strategic financial decision and managers must settle on the amount of debt in relation to equity that it requires to maintain. Popoola (2016) posits that determining the appropriate capital structure is one of the most important decisions of the financial management. Cole and Sokolyk (2017) established that decisions on the capital structure at the beginning of the firms' life are extremely significant for the survival and growth of these entities. Due to the significant financing constraints, high risk and uncertainty faced by new small firms, the investment capability and growth of these firms are also affected (Silva, 2015). The type of capital that a firm will use depends on the manager, the availability of funds and the type of business and other factors such as management, firm characteristics, management and firm performance and the environment (Matias \& Serrasqueiro, 2017; Nawi, 2015).

\section{Problem statement}

Due to SMMEs' heavy reliance on internally generated funds and lack of access to external finance, these firms experience slow or stagnant growth. According to Nawi (2015), academics have begun to question the capital structure theories in explaining small and medium size enterprises' capital structure. A number of capital structure financial theories (Modigliani \& Miller, 1958; Kraus \& Litzenberger, 1973; Donaldson, 1961; Myers \& Majluf, 1984) have attempted to explain firm's preferences and behavior according to the financing choice of that firm (Mokuoane, 2016). However, Matias and Serrasqueiro (2017) argue that capital structure theories do not fully explain the capital structure that SMMEs utilize due to these theories' existence before the establishment of SMMEs. Borgia and Newman (2012) also argue that these capital structure theories disregard the role played by managers' characteristics and attitudes, reiterating that identifying the factors that influence the capital structure is important for SMME firms. In addition, these capital structure financial theories explain the financing behavior of large enterprises. This raises a need for further research in debt and equity finance for SMMEs (Mokuoane, 2016).

The aim of this study is to identify factors influencing the capital structure for the survival and growth of small, medium and micro enterprises in a developing economy.

Objectives: 1) to establish factors that influence the capital structure used by SMMEs in a developing economy; 2) to suggest a capital structure that will seek to address financing challenges facing SMMEs in a developing economy.

\section{LITERATURE REVIEW}

\subsection{Capital structure defined}

Capital structure is defined by Gitman, Smith, Hall, Makina, Malan, Marx, Mestry, Ngwenya, and Strydom (2016) as the mixture of long-term debt and equity sustained by the firm. Popoola (2016) further expounds on the definition of capital structure as "the relationship between equity, preference share and debt capital". Nirajini and Priya (2013) concur with Gitman et al. (2016), stating that capital structure is a mix of financing approaches utilized by a firm. Capital structure also refers to the extent of debt and equity that makes up the liability section of a firm's balance sheet, often known as 'leverage'. The difference between debt capital and equity capital is that debt capital lenders do not become part owners of the firm, while equity capital suppliers can become part owners. Debt capital lenders are creditors who only receive fixed annual payments from the finances supplied. Debt may be short-term or long-term (Maina \& Ishmail, 2014). According to Gitman et al. (2016), the firm can acquire equity capital either internally through retained earnings or externally by selling a certain percentage of ownership from the firm, which results in these equity capital suppliers becoming part owners. Another 
difference between debt capital and equity capital noted by Gitman et al. (2016) is that equity capital is a permanent source of financing, while debt capital has a maturity date. From the term 'capital structure' has emerged 'optimal capital structure'. Defining the optimal capital structure is an essential and imperative decision. The ultimate goal of a financial manager is to maximize the shareholders' wealth, that is increasing the share price of the firm by ensuring an optimal mix of debt and equity in the firm.

According to Taiwo et al. (2016), one of the foremost sources of financing available to small firms is that of personal savings and informal loans from friends and lenders. Other sources include partners, informal financial markets and banks, which would make up the capital structure of a small business. Once the firm is established, retained earnings become imperative to these firms, particularly SMMEs (Taiwo et al., 2016). Fourati and Affes (2013) state that external funds are not available at the start-up stage for newly created firms. Due to this problem and given this difficulty, owners/managers rely heavily on internal funds. Ebiringa (2011) posits that external financing sources for start-up firms are limited to bank loans and trade credit and when these firms rely less on bank loans, they turn to leasing. Cotei and Farhat (2017) state that at the start-up stage, owners/managers rely on internal equity capital such as personal savings, funds from friends and family and personal debt. Elomo (2014) points out that start-up firms can finance the entity by using trade credit and leasing. Borgia and Newman (2012) posit that having a good relationship with managers from other firms also provides with better access to resources, which may allow access to informal sources of funds. Borgia and Newman (2012) citing Xiao (2011) established that informal financial sources, such as individuals and employees, were essential and these sources have become a vital part of the financial infrastructure for the private sector in China, although these may not be reflected on the statement of financial position. In financial literature, external finance is widely recognized as including both debt and equity. These finances are crucial for small firms to survive and grow. According to Ogubazghi and Muturi (2014), SMMEs face difficulty in accessing external equity due to the inefficient external equity market of developing countries.

\subsection{The determinants of capital structure}

According to Gwatidzo, Ntuli, and Mlilo (2016), significant research has been disbursed in acquiring a superior understanding of firms' financing decisions. Onaolapo, Kajola, and Nwidobie (2015) explain that "there is no consensus in the determinants of capital structure for developed and developing countries" due to the adoption of different methodologies and choices in time frame. Handoo and Sharma (2014) state that realizing the correct capital structure to support its operations and ventures has tested academics and experts alike and the capital structure choice is the most vital financial outline issue of a firm. This period has seen many forms of firms starting to over-leverage, which is self-imposed by the managers of these firms, as they make the decision on how much debt to take on.

A study conducted by Handoo and Sharma (2014) examined 870 companies in India to establish which factors influence capital structure choices, especially with India's emerging economy using firm-specific data. The firm-level factors such as profitability, growth, asset tangibility, size, cost of debt, liquidity, financial distress, rate of taxation, debt servicing capacity and age of firms were investigated. The findings of the study reveal that profitability, growth, asset tangibility, size, tax rate, debt serving produced a significant impact on total debt, while cost of debt, liquidity, financial distress and age do not substantially have an impact on total debt. Their study concluded that capital structure management becomes a "balancing act" and firms must make a trade-off between financial flexibility and financial discipline (Handoo \& Sharma, 2014).

Chipeta and Deressa's (2016) study assessed the effect of firm-level factors on the dynamics of the capital structure of 12 Sub-Saharan African countries. The study included country-specific factors by carrying out panel data estimate techniques on a set of 412 firms over the period 2008-2012. The firm-level factors investigated were "size, growth, profitability, tangibility, risk and tax, while the country-specific factors are rule of law, control of corruption, legal rights index, contract enforcement days, cost of enforcement, stock market cap- 
italisation to GDP, private sector credit to GDP, real GDP and real interest rate" (Chipeta \& Deressa, 2016). The findings of the study established size to be "positive and significant" for $50 \%$ of the countries which form part of the sample, while growth was only significant for $25 \%$ of the countries that were sampled. Profitability was found to be negative and statistically significant for 11 of 12 firms, which confirms the pecking order financing theory (consistent with Thippayana, 2014). Asset tangibility indicated mixed results across the countries, with South Africa showing a "positive and significant correlation between asset tangibility and leverage" (Chipeta \& Deressa, 2016). The afore-mentioned result is coherent with the theory that "firms with tangible assets will be less exposed to potential costs of financial distress" (Thippayana, 2014). This is dissimilar to the notion that companies endowed with assets that constitute a high collateral value will possess high debt ratios. In terms of risk, South Africa and Tanzania displayed statistically significant and negative coefficients, suggesting that highly volatile earnings relate to "lower leverage for firms in these two countries, while tax was also found to be statistically significant for firms in a third of the sampled countries" (Chipeta \& Deressa, 2016). Onaolapo et al. (2015) investigated the determinants of corporate capital structure using published annual reports that meet the Nigerian Companies and Allied Matters Act 2004, Nigerian Stock Exchange (NSE) and Securities and Exchange Commission over the period 2006-2012, using pooled ordinary least squares to estimate the coefficient of six firm-specific determinants: "profitability, asset tangibility, growth opportunities, size, non-debt tax shields and dividend pay-out".

\subsection{Factors influencing the capital structure used by SMMEs}

A study by Nawi (2015) investigated the factors of capital structure in SMMEs in Malaysia and their influence on performance. The study examined the factors influencing the capital structure of small businesses, including owner/manager traits, firm characteristics, management performance, external factors and ethnicity. The determinants investigated in the study were "owner's age; race (ethnicity); education and experience; attitude; perceptions and beliefs; relationship and networking; objectives and goals; firm's age; firm's size; profitability; asset structure; business planning; and environment" (Nawi, 2015). Capital structure was measured using retained earnings, funds from friends and families and debt. The study had a sample of 384 firms (67\% sole proprietorship, $13 \%$ partnership and $20 \%$ limited liability), using a mixed method approach, with the main study using questionnaires. Semi-structured interviews were conducted at the preliminary stage to explore issues and finalize questionnaires (Nawi, 2015). Although limited research has been conducted on owners' preferences, views and attitudes influencing their financing decisions, the study included management preference in terms of risk propensity, control aversion and culture norm (Nawi, 2015; Mac an Bhaird \& Lucey, 2014). According to Hilgen (2014), the essence of culture is the way people think, feel and act, which can be distinguished through behavioral patterns, values, beliefs and assumptions.

The results showed that "all firm characteristics were found to be significant in at least one of the sources of finance" (Nawi, 2015). Retained earnings were found to be "positively associated with firm's age and profitability and inversely related to business planning and asset structure"; however, in relation to funds from friends and family, firm's age and business planning were negatively related (Nawi, 2015). Debt financing was found to be "positively associated with business planning and asset structure, but negatively associated with firm age and profitability"; on the other hand, external equity was "positively associated with firm size and business planning and negatively related to profitability" (Nawi, 2015).

Owners' ethnicity, networking and relationships and attitudes to debt were found to influence Malaysia's small business capital structure, with the owner's age and education having no influence (Nawi, 2015). The overall results indicate a nil signal that links capital structure decisions with the education and experience of firm owners. The findings also revealed that "managerial factors, firm characteristics, management performance and environment relate to all types of capital structure", supporting the pecking order theory (Nawi, 2015). 
In addition, a study conducted by Matias and Serrasqueiro (2017) analyzed capital structure factors connected "to the firm's intrinsic characteristics". The study investigated the possible presence of dissimilarities in the structure of capital and 'firm-level' factors of SMMEs across the country. Matias and Serrasqueiro (2017) agree with other studies that the modern financial theories are deficient in expounding on the decisions taken to influence the structure of capital of small, enterprises as these theories are based on the decision making of maximizing the firm's value. Although there has been large-scale scientific research on the connection between the value of a firm and the capital structure, there seems to be a lack of shared understanding and agreement among scholars (Vo \& Ellis, 2016). The study examined the period between 2007 and 2011 for 11,016 sample companies' financial data, which were provided by the Bureau van Dijik, covering seven Portuguese regions. The study focused on the following factors: size, profitability, age, asset tangibility, growth and debt (Matias \& Serrasqueiro, 2017). The findings revealed that Portuguese owners/managers fund small firms with a larger portion of debt rather than equity, which was observed in all regions (Matias \& Serrasqueiro, 2017).

The results showed that the average size was comparatively alike in the diverse regions, with a major difference in two regions. Profitability averaged around 5\%, with firms in the Lisbon region being the most profitable. In addition, it was reported that "the relationships between size and debt (short, medium and long-term) were positive and statistically significant for the majority of the regions for the sample" (Matias \& Serrasquerios, 2017). Profitability and long and medium-term debt were found to be negatively related, with only two regions found not to be statistically significant. The association between firm age and debt was discovered to adversely affect total debt and short-term debt, while it was found to positively affect medium-term debt. Age was found to best explain the level of short-term debt in four regions. Tangible assets were found to positively affect levels of total debt and long-term debt, but negatively affected short-term debt.

\section{RESEARCH METHODOLOGY}

This study adopted a quantitative approach and was cross-sectional. Cross-sectional research includes the accumulation of data in excess of one case at a single point in time (Bryman \& Bell, 2014). According to Sekaran and Bougie (2011), cross-sectional studies consider data that are assembled once, maybe over a period of days, weeks or month, to answer the research question. A survey questionnaire was viewed as most suitable in this study. The questions consisted of dichotomous, multiple-choice and Likert scale questions. The questionnaire had closed-ended questions. Data entry was undertaken using the computer software program PLS-SEM 5.0 for data analysis. Composite Reliability (CR) was used to estimate the consistency of individual responses to items within a scale (Shin, 2009). CR offers a retrospective method of the overall reliability measure of a factor in the questionnaire. It approximates the consistency of the factor itself, the steadiness and uniformity of the factor (Roca, Garcia, \& De La Vega, 2009; Suki, 2011). As shown in Table 1 , all values of CR and Cronbach's alpha (CA) coefficient met the commended threshold of 0.70 to indicate good reliability for the factors (Fornell \& Larcker, 1981; Henseler, Ringle, \& Sinkovics, 2009; Bagozzi \& Yi, 2012). The value with an asterisk $\left.{ }^{*}\right)$ of 0.490 , together with the corresponding consistent reliability coefficient (rho_A), were, however, suspect, but were maintained to ensure face consistency for the rest of the factors (Henseler et al., 2009).

AVE is largely recognized as the measure of convergent validity for measurement models. According to Henseler et al. (2009), the AVE "establishes the amount of variance that a factor captures from its measurement items". Suki (2011) states that discriminate validity is a test that measures reliability and it is the degree to which a known theory is sig-

Table 1. Construct reliability and validity

\begin{tabular}{l|c|c|c:c}
\hline \multicolumn{1}{c}{ Factors } & Cronbach's alpha & rho_A & Composite reliability & Average variance extracted (AVE) \\
\hline CapStrFirm & $0.490^{*}$ & $0.497^{*}$ & 0.796 & 0.662 \\
CapStrSurGrth & 0.851 & 1.005 & 0.904 & 0.761 \\
FinInfoFirm & 0.741 & 0.877 & 0.826 & 0.548 \\
InfoFirm & 1.000 & 1.000 & 1.000 & 1.000 \\
\hline
\end{tabular}


Table 2. Discriminant validity: Fornell-Larcker criterion

\begin{tabular}{l|c|c|c|c}
\hline \multicolumn{1}{c}{ Factors } & CapStrFirm & CapStrSurGrth & FinInfoFirm_ & InfoFirm \\
\hline CapStrFirm & 0.813 & - & - & - \\
CapStrSurGrth & -0.302 & 0.872 & - & - \\
FinInfoFirm & -0.078 & 0.069 & 0.740 & - \\
InfoFirm & 0.017 & 0.126 & 0.129 & 1.000 \\
\hline
\end{tabular}

nificantly different as compared to other theories. A commonly used test for discriminant validity is to contrast the AVE with the interrelated squared root (Ibrahim \& Shiratuddin, 2015; Fornell \& Larcker, 1981). To pass this test, the AVE of a theory must be higher than the square root of the inter-factor relationships (Fornell \& Larcker, 1981). In other words, when displayed in diagonal format, the diagonal values should surpass the inter-factor correlations to prove discriminant validity. As evidenced from Table 2, the diagonal values in bold exceed the inter-factor correlations. It can therefore be concluded that discriminant validity was acceptable. Therefore, the measurement scales have enough validity and demonstrate high reliability.

\section{RESEARCH FINDINGS}

\subsection{Factors affecting financing decisions}

Figure 1 shows factors affecting financing decisions. These are discussed below.

\subsection{Attitude to debt}

Figure 1 displays which factors are important when respondents are making financial decisions for the firm. From the figure above, it is seen that majority of respondents (75\%) indicated that attitude towards debt is either an important or very important factor when making financial decision for the firm. On the other hand, $13 \%$ gave a neutral response. Only $2 \%$ indicated that attitude towards debt is not important and $10 \%$ do not consider attitude towards debt being important at all. The study claims that attitude to debt is an important factor that influences the financing decisions for the firm. The results also confirm a study by Nawi (2015) that discovered that the traits of the owner in terms of attitude to debt were an important factor in the financing choice for the firms.

\subsubsection{Culture norms}

Figure 1 indicates that $68 \%$ of respondents indicated that culture norms are either important or

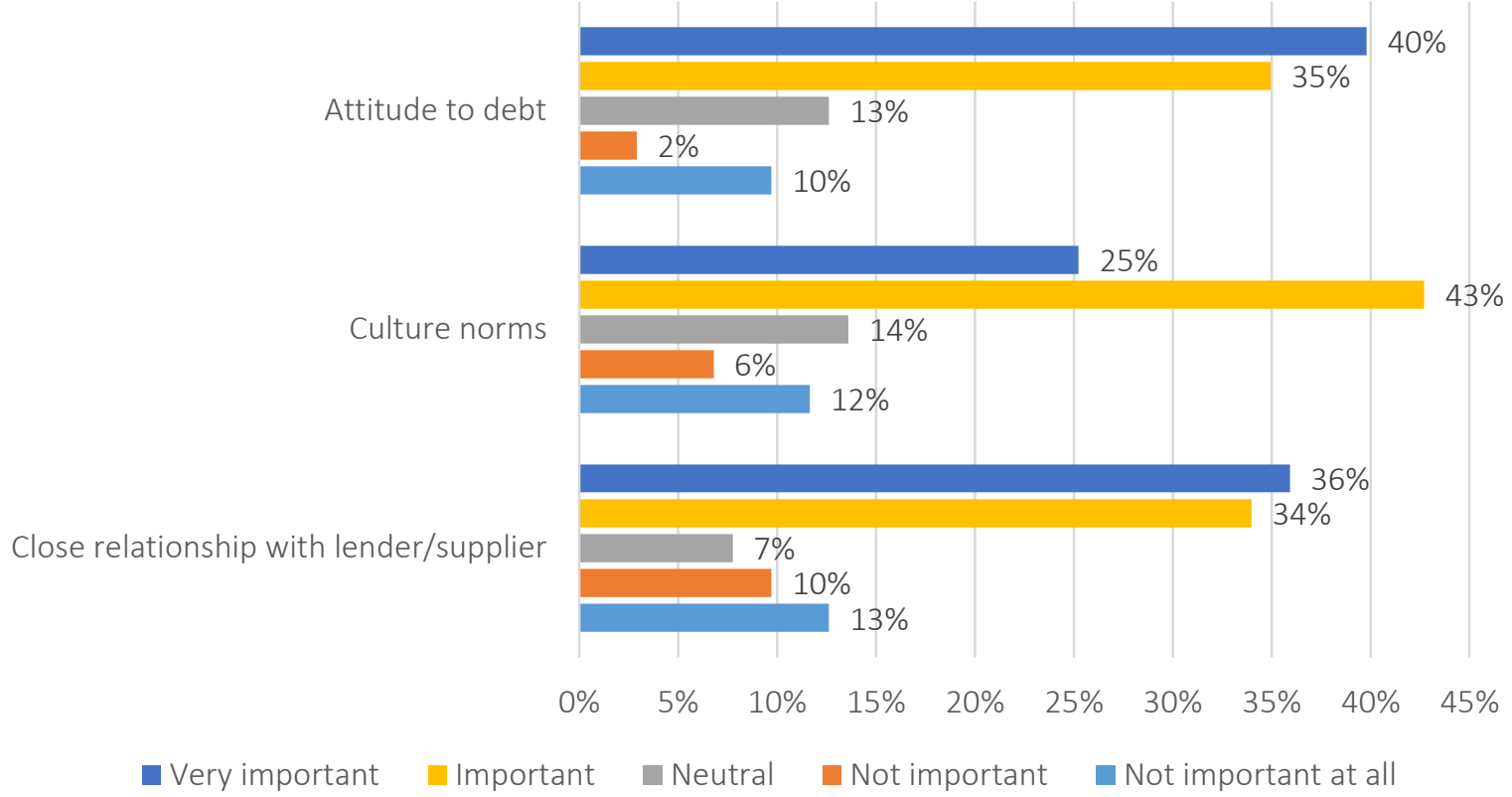

Figure 1. Factors affecting financial decisions 
very important to the financial decisions for the firm and $14 \%$ indicated a neutral response. Only $6 \%$ of the respondents indicated that culture norms are not an important factor affecting the financial decisions for the firm and $12 \%$ indicated that culture norms were not important at all. Hilgen (2014) states that cultural influences have been recognized to be an important factor for the firms. The findings correlate with Nawi (2015) that culture norms are the most important factor to financing decisions for the firm.

\subsubsection{Close relationship with lenders/suppliers}

The factor of having a close relationship with lenders/suppliers indicated in Figure 1 shows that $70 \%$ of respondents consider this as either important or very important factor to the financial decisions for the firm and $7 \%$ indicated a neutral response. Only $10 \%$ of respondents indicated that having a close relationship with the lender/supplier is not an important factor when financial decisions for the firm are made and $13 \%$ indicated that this factor was not important at all. These results reveal that close relationship with lenders/suppliers is important to the financial decisions for the firm. According to Nawi (2015), the relationship with outsiders plays a key role in shaping financial decisions.

\subsection{Factors likely to influence the firm's capital structure}

Figure 2 illustrates the factors, which are likely to influence SMMEs' capital structure. These factors include external stakeholders, profitability of the firm, size and age of the firm.

\subsubsection{External stakeholders}

In Figure 2, a little above 58\% of respondents indicated that they agreed that external stakeholders are likely to influence the capital structure of the firm, $12 \%$ neither agreed nor disagreed, and 30\% indicated that external stakeholders are not likely to influence the capital structure of the firm. These findings indicate that external stakeholders are likely to influence the capital structure of SMMEs.

\subsubsection{Profitability of the firm}

From Figure 2, the majority of respondents (97\%) indicated that they agreed that profitability was likely to influence the firm's capital structure and 3\% of respondents disagreed with this statement. These result reveal that profitability is likely to influence the firm's capital structure. According to Chipeta and Deressa (2016), firm profitability was found to be the most significant factor of capital structure.

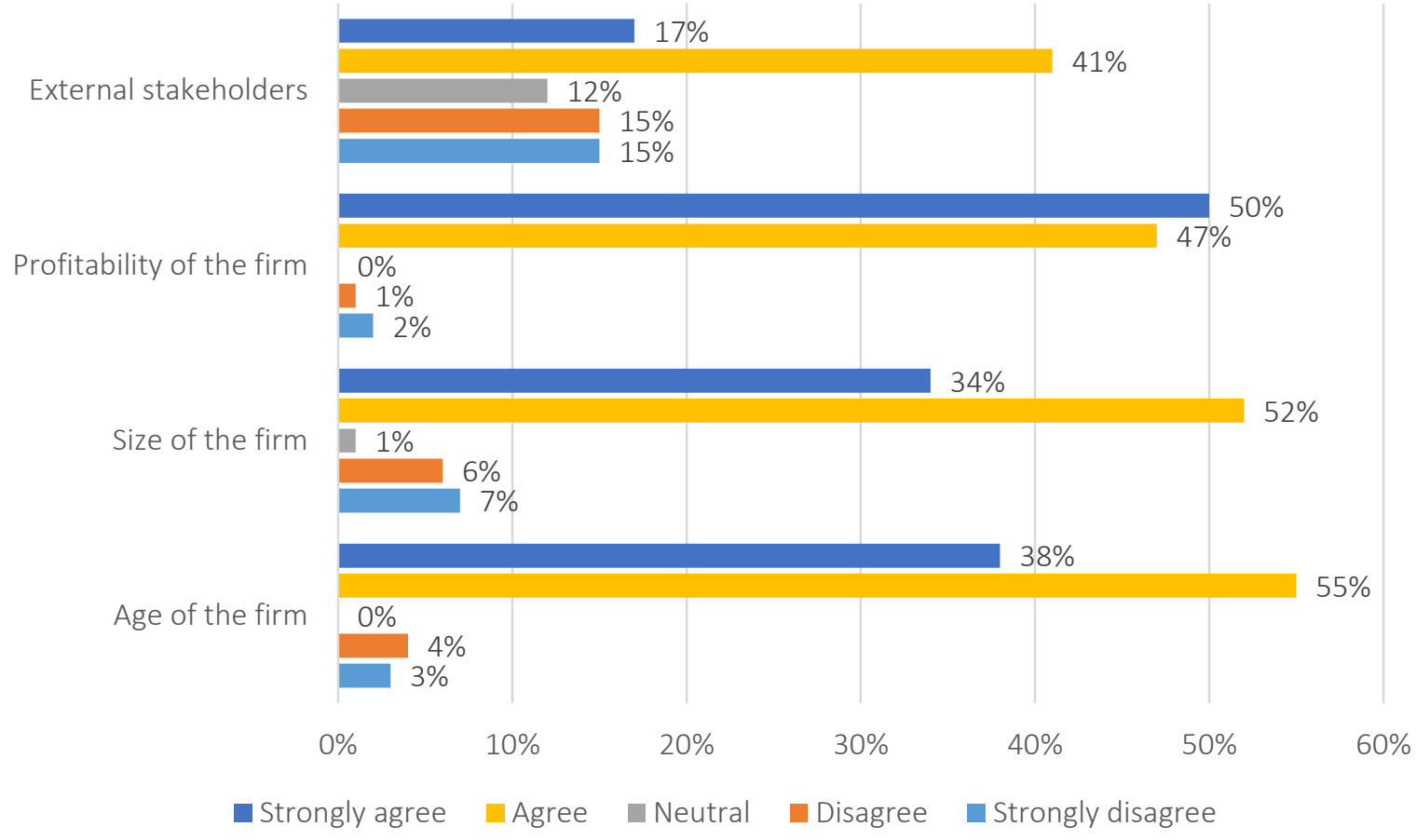

Figure 2. Factors likely to influence firm's capital structure 


\subsubsection{Size of the firm}

Figure 2 shows that the majority of respondents $(86 \%)$ indicated that they agreed that the size of the firm is likely to influence the capital structure of the firm, $13 \%$ of respondents disagreed with this statement; and $1 \%$ neither agreed nor disagreed. These results reveal that the size of the firm is likely to influence the firms' capital structure. Thippayana (2014) established the size to be significant for half of the sampled countries in the study.

\subsubsection{Age of the firm}

From Figure 2, the majority of respondents (93\%) agree that the age of the firm is likely to influence the firm's capital structure. Only 7\% of respondents disagreed that the age is likely to influence the firm's capital structure. These result reveal that the age of the firm is likely to influence the firm's capital structure. According to Bassey, Arene, and Okpukpara (2014), size is important for firms in securing longterm debt.

\section{RECOMMENDATIONS}

\subsection{Recommendations for SMMEs}

Findings revealed that the owner's/manager's attitude to debt has an influence on the finan- cial decisions for the firm. Therefore, owners/ managers need to determine whether the attitude they have towards debt is hindering the firm from acquiring debt, which can assist it to finance the growth aspirations of the owner/ manager. The study recommends that owners/ managers build a relationship with lenders to better understand the benefits and difficulties of using debt for the firm and the owner/manager. This exercise can better assist owners/managers to make more informed decisions with regard to debt, not basing financing decisions on their attitude, while providing managers with the financial assistance they require to grow and for SMME survival.

\subsection{Recommendations for future research}

The current study was limited to the retail and whole sector, which is the second largest sector in KwaZulu-Natal. Hence, this study recommends that future studies should include other sectors to determine whether SMME capital structures are influenced by similar factors. A comparative study is also recommended of SMME in different regions and countries to enrich an understanding of SMMEs capital structure patterns.

\section{CONCLUSION}

The sample was restricted to retail and wholesale SMMEs located in Durban, KwaZulu-Natal, South Africa. Considering that the study only focuses on SMMEs in Durban, the findings can be generalized with care to SMMEs in other developing markets, as the conditions and characteristics may differ considerably. The study also used structured questionnaires.

The results of this study have implications on the capital structure theories. The key theories of capital structure are the trade-off theory and pecking order theory, which are based on firm-level factors. The findings of the study revealed that both managerial and firm-level factors affect the capital structure. Current empirical findings suggest that SMME owners/managers utilize internally generated funds in the capital structure. Findings revealed that traditional capital structure theories may not clarify the financing conduct of SMMEs. Capital structure decisions are made by owners/managers of SMMEs, driven by the attitudes of these owners/managers. 


\section{REFERENCES}

1. Abeywardhana, Y. K. D. (2015). Capital structure theory and profitability: an empirical analysis of SME's in the UK. Journal of Emerging Issues in Economics, 4(2), 1661-1675. Retrieved from https://www.researchgate.net/ publication/285596953_Capital_Structure_and_Profitability_An_Empirical_Analysis_of_ SMEs_in_the_UK

2. Agwa-Ejon, J., \& Mbohwa, C. (2015). Financial challenges faced by SMMES in Gauteng South Africa. In International Association for Management of Technology IAMOT 2015 Conference Proceedings (pp. 520-534). Retrieved from http://iamot2015. com/2015proceedings/documents/P065.pdf

3. Bagozzi, R. P., \& Yi, Y. (2012). Specification, evaluation, and interpretation of structural equation models. Journal of the Academy of Marketing Science, 40(1), 8-34. Retrieved from https://link.springer. com/article/10.1007/s11747-0110278-x

4. Bassey, N. E., Arene, C. J., \& Okpukpara, B. C. (2014). Determinants of capital structure of listed agro firms in Nigeria. Economic Affairs, 59(1), 35-47. http://dx.doi. org/10.5958/j.0976-4666.59.1.004

5. Borgia, D. B., \& Newman, A. (2012). The influence of managerial factors on the capital structure of small and medium sized enterprises in emerging economies: evidence from China. Journal of Chinese Entrepreneurship, 4(3), 180-205. https://doi. org/10.1108/17561391211262148

6. Bryman, A., \& Bell, E. (2014). Research methodology: business and management contexts. Cape Town: Oxford University Press.

7. Chipeta, C., \& Deressa, C. (2016). Firm and country specific determinants of capital structure in Sub Saharan Africa. International Journal of Emerging Markets, 11(4), 649-673. https://doi.org/10.1108/ IJoEM-04-2015-0082
8. Cole, R., \& Sokolyk, T. (2017). Debt financing, survival and growth of start-up firms. Journal of Corporate Finance, 50, 609-625. https://doi.org/10.1016/j.jcorpfin.2017.10.013

9. Cotei, C., \& Farhat, J. (2017). The evolution of financing structure in U.S. startups. The Journal of Entrepreneurial Finance, 19(1), 105-138. Retrieved from https:// digitalcommons.pepperdine.edu/ jef/vol19/iss1/4/

10. Donaldson, G. (1961). Corporate debt capacity: A study of corporate debt policy and the determination of corporate debt capacity. MA., Harvard University. Retrieved from https:// books.google.com.ua/books/ about/Corporate_Debt_Capacity. html?id=PKxQHviLwasC\&redir esc $=y$

11. Ebiringa, O. T. (2011). Synthesis on small and medium enterprise (SME) start-up financing. International Journal of Economy Research, 2(1), 85-95.

12. Elomo, P. N. (2014). Determinants of capital structure of start-up firms in SA. MA., University of the Witwatersrand. Retrieved from http:// hdl.handle.net/10539/16949

13. Fornell, C., \& Larcker, D. F. (1981). Evaluating Structural Equation Models with unobservable variables and measurement error. Journal of Marketing Research, 18(1), 39-50. https://doi. org/10.2307/3151312

14. Fourati, H., \& Affes, H. (2013). The capital structure of business start-up: Is there a pecking order theory or a reversed pecking order? - evidence from the panel study of entrepreneurial dynamics. Technology and Investment, 4, 244-254. https://doi.org/10.4236/ ti.2013.44029

15. Gitman, L. J., Smith, M. B., Hall, J., Makina, D., Malan, M., Marx, J., Mestry, R., Ngwenya, S., \& Strydom, B. (2016). Principles of Managerial Finance (2nd ed.). Cape Town: Pearson Education Limited.
16. Gwatidzo, T., Ntuli, M., \& Mlilo, M. (2016). Capital structure determinants in South Africa: A quantile regression approach. Journal of Economic and Financial Sciences, 9(1), 275-290. https://doi. org/10.4102/jef.v9i1.42

17. Handoo, A., \& Sharma, K. (2014). A study of determinants in India. Indian Institute of Management Bangalore, 26, 170-182. https://doi. org/10.1016/j.iimb.2014.07.009

18. Henseler, J., Ringle, C. M., \& Sinkovics, R. R. (2009). The use of partial least squares path modeling in international marketing. In Rudolf, R., Sinkovics, Pervez N. Ghauri (Eds.). New Challenges to International Marketing. Advances in International Marketing, 20 (pp. 277-319). Emerald Group Publishing Limited. https://www.emeraldinsight. com/doi/abs/10.1108/S1474 7979\%282009\%290000020014

19. Hilgen, M. (2014). The impact of cultural clusters on capital structure decisions: evidence from European retailers (Working papers). Retrieved from https://essay.utwente. nl/65312/1/hilgen_BA_MB.pdf (accessed on August 31, 2018).

20. Ibrahim, N., \& Shiratuddin, M. F. (2015). Instruments for measuring the influence of visual persuasion: validity and reliability tests. European Journal of Social Sciences, 2(3), 25-37. http://dx.doi. org/10.26417/ejser.v4i1.p25-37

21. Kraus, A., \& Litzenberger, R. H. (1973). A state-preference model of optimal financial leverage. The Journal of Finance, 28(4), 911-922. https://doi.org/10.2307/2978343

22. Mac an Bhaird, C., \& Lucey, B. (2014). Culture's influences: an investigation of inter-country differences in capital structure. Borsa Istanbul Review, 14(1), 1-9. https:// doi.org/10.1016/j.bir.2013.10.004

23. Maina, L., \& Ishmail, M. (2014). Capital structure and financial performance in Kenya: evidence from firms listed at the Nairobi securities exchange. International Journal of Social Sciences and Entrepreneurship, 1(11), 209-223. 
24. Matias, F., \& Serrasqueiro, Z. (2017). Are there reliable determinant factors of capital structure decisions? Empirical study of SMEs in different regions of Portugal. Research in International Business and Finance, 40, 19-33. https://doi.org/10.1016/j. ribaf.2016.09.014

25. Modigliani, F., \& Miller, M. H. (1958). The cost of capital, corporation finance and the theory of investment. American Economic Review, 48(3), 261-297. Retrieved from https://www.jstor.org/ stable/1809766?seq=1\#page_scan_ tab_contents

26. Mokuoane, M. (2016). Capital structure under different macroeconomic conditions: evidence from South Africa. M. Com., dissertation, Wits University.

27. Myers, S. C., \& Majluf, N. S. (1984). Corporate financing and investment decisions when firms have information that investors do not have. Journal of Financial Economics, 13(2), 187-221. https://doi.org/10.1016/0304405X(84)90023-0

28. Nawi, H. M. (2015). Determinants of capital structure in small and medium-sized enterprises in $\mathrm{Ma}$ laysia. D. Phil., Brunel University.

29. Nirajini, A., \& Priya, K. B. (2013). Impact of capital structure on financial performance of listed trading companies in Sri Lanka. International Journal of Scientific and Research Publications, 3(5),
35-43. Retrieved from http://www. ijsrp.org/research-paper-0513. php?rp=P171190

30. Ogubazghi, S. K., \& Muturi, W. (2014). The effect of age and educational level of owner/managers on SMMEs' access to bank loan in Eritrea: evidence from Asmara City. American Journal of Industrial and Business Management, 4, 632-643. http://dx.doi. org/10.4236/ajibm.2014.411069

31. Onaolapo, A. A., Kajola, S. O., \& Nwidobie, M. B. (2015). Determinants of capital structure: a study of Nigerian quoted companies. European Journal of Business and Management, 7(23), 170-183.

32. Popoola, R. A. (2016). An analysis of capital structures of listed industrial companies in South Africa. M. Tech., Vaal University of Technology.

33. Roca, J. C., Garcia, J. J., \& De La Vega, J. J. (2009). The importance of perceived trust, security and privacy in online trading systems. Information Management and Computer Security, 17(2), 96-113. https://doi. org/10.1108/09685220910963983

34. Sekaran, U., \& Bougie, R. (2011). Research methods for business: a skill building approach (5th ed.). Chichester: John Wiley and Sons. Retrieved from https://www.wiley. com/en-us/Research+Methods+F or+Business $\% 3 \mathrm{~A}+\mathrm{A}+$ Skill+Build ing + Approach $\% 2 \mathrm{C}+7$ th + Edition -p-9781119266846
35. Shin, D. H. (2009). An empirical investigation of a modified technology acceptance model of IPTV. Behavior and Information Technology, 28(4), 361-372. https://doi. org/10.1080/01449290701814232

36. Silva, F. M. M. C. (2015). The impact of capital structure on startups' growth. MA., University of Porto.

37. Suki, N. M. (2011). A structural model of customer satisfaction and trust in vendors involved in mobile commerce. International Journal of Business Science and Applied Management, 6(2), 1830. Retrieved from http://www. business-and-management.org/ paper.php?id=70

38. Taiwo, J. N., Falohun, T., \& Agwu, M. E. (2016). SMEs financing and its effects on Nigerian economic growth. European Journal of Business, Economics and Accountancy, 4(4), 37-54. Retrieved from https://papers.ssrn.com/sol3/papers.cfm?abstract_id $=3122457$

39. Thippayana, P. (2014). Determinants of capital structure in Thailand. Procedia - Social and Behavioral Sciences, 143, 10741077. https://doi.org/10.1016/j. sbspro.2014.07.558

40. Vo, X. V., \& Ellis, C. (2016). An empirical investigation of capital structure and firm value in Vietnam. Finance Research Letters, 22, 90-94. https://doi.org/10.1016/j. frl.2016.10.014 